\title{
The assessment of quality of life and satisfaction with life of patients before and after surgery of an isolated apical defect using synthetic materials
}

\author{
Maciej Zalewski ${ }^{1,2}$, Gabriela Kołodyńska ${ }^{3^{*}}$ (D, Anna Mucha ${ }^{4}$, Łukasz Bełza², Krzysztof Nowak² and \\ Waldemar Andrzejewski ${ }^{3,5}$
}

\begin{abstract}
Background: Pelvic floor static disorders constitute a significant clinical and social problem. The incidence of the problem increases with the age of female patients up to 80 years of age. Due to various methods of procedural treatment, eligibility for surgery should be carefully discussed with the patient. Ideally, the surgery should be effective and with the least possible number of complications. The objective of this study was to assess the quality of life of patients before and after the surgery of an isolated apical defect with the use of BSC mesh.

Methods: The study involved 60 patients who were diagnosed with pelvic floor static disorder on the basis of physical examination. Standardised questionnaires were used to assess the quality of life and satisfaction with life: the Perceived Quality of Life (P-QOL) and the Satisfaction With Life Scale (SWLS).

Results: The P-QOL results for each domain were higher in patients before surgery compared to the results obtained after the surgery. For almost all domains, the results obtained were statistically significant. The results obtained in the SWLS questionnaire in most answers also show that after the procedure there was an improvement in satisfaction with life in the examined female patients.
\end{abstract}

Conclusion: In most patients, surgical treatment of an isolated apical defect using BSC mesh results in the subsidence of bothersome symptoms and improves the quality of life.

Keywords: Isolated apical defect, Quality of life, Surgical treatment

\section{Background}

Pelvic organ prolapse (POP) constitutes a significant clinical and social problem. The symptoms worsen when intra-abdominal pressure increases, for instance during physical activity or coughing. The number of patients suffering from pelvic organ prolapse is not exactly known due to different definitions of the disorder and

\footnotetext{
* Correspondence: kolodynska.gabriella@gmail.com

${ }^{3}$ Department of Physiotherapy, University School of Physical Education, Wrocław, Poland

Full list of author information is available at the end of the article
}

various systems of classification. According to the latest European data, the ailment concerns approximately $6-$ $11 \%$ of women. American data suggest that the disorder is found in about $24 \%$ of women. The incidence of the problem increases with the age of female patients up to 80 years of age. In such cases, the need to perform surgery is determined in $20 \%$ of women [1-3].

Currently, the basic indication for surgical treatment is the occurrence of symptoms and ineffective conservative treatment. and the lack of consent of the patient for conservative treatment or ineffective conservative treatment.

(c) The Author(s). 2020 Open Access This article is licensed under a Creative Commons Attribution 4.0 International License, which permits use, sharing, adaptation, distribution and reproduction in any medium or format, as long as you give appropriate credit to the original author(s) and the source, provide a link to the Creative Commons licence, and indicate if changes were made. The images or other third party material in this article are included in the article's Creative Commons licence, unless indicated otherwise in a credit line to the material. If material is not included in the article's Creative Commons licence and your intended use is not permitted by statutory regulation or exceeds the permitted use, you will need to obtain permission directly from the copyright holder. To view a copy of this licence, visit http://creativecommons.org/licenses/by/4.0/. The Creative Commons Public Domain Dedication waiver (http://creativecommons.org/publicdomain/zero/1.0/) applies to the data made available in this article, unless otherwise stated in a credit line to the data. 
Surgery may be warranted if if there are symptoms associated with prolapse such as:

- strain and/or pain in the lower abdomen;

- urinary and/or faecal incontinence;

- recurrent bladder ailments (urinary urgency or pollakiuria);

- difficulty urinating and/or defecating;

- the need to change body position in order to urinate:

- limited sexual activity [4].

Due to various methods of procedural treatment, eligibility for surgery should be carefully discussed with the patient. Ideally, the surgery should be effective and with the least possible number of complications.

In 1990, A. Wattiez [5] performed the first laparoscopic sacrocolpopexy, which is a gold standard for treating pelvic floor static disorders [6]. The surgery gives very good treatment results in the absence of complications typical for vaginal mesh implants [7].

Therefore, new solutions have appeared, such as Noe's [8] pectopexy (the suspension of the Cooper's ligament) and the Dubuisson's laparoscopic lateral suspension [9].

Nevertheless, it seems that in the case of older patients with a history of internal diseases, for whom laparoscopic or abdominal surgeries under general anaesthesia may pose too high risks, the only alternative is transvaginal surgery. Many vaginal approaches to apical suspension have been described [10-12]. Therefore, it is necessary to find a method which would combine low invasiveness of transvaginal surgery with high efficiency [13].

Pelvic organ prolapse significantly reduces the quality of life for women $[14,15]$. The most common problems include incomplete bladder voiding, chronic urine retention, interrupted or impeded urination, as well as the need to support urination by engaging the abdominal prelum or the need to change body position in order to urinate $[16,17]$. Nowadays, doctors not only focus on extending the life of their patients, but also on improving its quality. Contemporary medicine aims to improve the quality of life of the patient to the condition from before the disease. Therefore, researchers are increasingly interested in assessing quality of life of people affected by various diseases $[18,19]$.

The objective of this study was to assess the quality of life of patients before and after performing the surgery of an isolated apical defect using BSC synthetic mesh.

\section{Material and methods}

\section{Design and data collection}

The study involved 60 patients from the Gynaecology Department of the Hospital of the Ministry of Internal
Affairs and Administration in Wroclaw, who were diagnosed with pelvic floor static disorders. The POP-Q scale and the modified classification of pelvic static disorders according to DeLancey were used to objectively assess the type and degree of the disorder (Table 1).

[Persu C, Chapple CR, Cauni V. Pelvic Organ Prolapse Quantification System (POP-Q) - a new era in pelvic prolapse staging. J Med Life. 2011; 15 4(1): 79.]

All patients qualified for the study had an isolated apical defect POP-Q III C or POP-Q IV C. The vast majority were, however, patients with POP-Q III C. The aim of the study was to assess the quality of life in another less common group of patients. Before the beginning of the study, informed consent was obtained from all patients to participate in the study. All qualified patients completed the P-QOL and the SWLS questionnaires twice: before the surgery and 12 months after surgery. Patients were qualified for the study on the basis of specific inclusion criteria.

The inclusion criteria were the following:

- Patients with an isolated apical defect;

- Reproductive organ static disorder grade III or IV of the POP-Q scale;

- Level I defect on the modified DeLancey scale;

- Lack of consent to pessary treatment;

- Ineffective conservative treatment

- Age over 65.

All patients qualified for the project had a cervical or vaginal stump suspension procedure performed using the AMI BSC system. The BSC mesh is designed to induce neo-ligament formation by establishing a symmetrical, two-sided vaginal vault suspension from sacral cruciate ligament. The BSC mesh provides support that was previously provided by natural ligaments that no longer work [20]. In this case, the mesh is fixed with iStitch-sutured fixation directly to the sacrospinous ligament. The surgical technique used included:

- pre-operative treatment (estriol aplication - 4 weeks before surgery, antibiotic prophylaxis with a combination of cephalosporin and metronidazole aplication, vaginal disinfection, anus covering);

- incision in the posterior vaginal wall $(3 \mathrm{~cm}$ distal to the vaginal apex);

- access to the sacrospinous ligament (a canal designated to admit the index finger of the surgeon is formed by advancing Metzenbaum scissors immediately under the vaginal wall horizontally in the direction of the pelvic side wall);

- dissection of a horizontal space under the cranial vaginal tissue (from the upper end of the longitudinal vaginal incision, the tissues of the 
Table 1 Stages of POP-Q system measurement

\begin{tabular}{ll}
\hline Stage $\mathbf{0}$ & no prolapse is demonstrated \\
\hline Stage $\mathbf{1}$ & the most distal portion of the prolapse is more than $1 \mathrm{~cm}$ above the level of the hymen \\
Stage $\mathbf{2}$ & the most distal portion of the prolapse is $1 \mathrm{~cm}$ or less proximal or distal to the hymenal plane \\
Stage 3 & the most distal portion of the prolapse protrudes more than $1 \mathrm{~cm}$ below the hymen but no farther \\
than $2 \mathrm{~cm}$ less than the total vaginal length (for example, not all of the vagina has prolapsed). \\
Stage 4 & vaginal eversion is essentially complete \\
\hline
\end{tabular}

rectovaginal septum are dissected off the posterior aspect of the vaginal wall);

- choosing the future fixation points for the BSC Mesh (it is a matter of personal preference, on which side the i-Stitch suture is placed first, the suture is advanced into the receiving groove, the sutures are not knotted but guided laterally to the thighs of the patient where they are held i.e. by short Kocher clamps);

- fixation of the tape to the underside of the vaginal apex or the posterior or anterior aspect of the cervix with 3 or 4 non absorbable polypropylene threads

- threading the sutures through the mesh (the prepositioned sutures are threaded through the mesh from posterior to anterior);

- Tyning of the sutures and cut short, bringing the mesh in contact with the patient's tissue for the first time, the vaginal incision is closed with the prepositioned running suture);

- Preparation for postoperative care (insertion of estriol ointment into the vagina, weekly prescribing vaginal estriol applications) [21].

\section{Measures}

1. The Perceived Quality of Life (P-QOL) questionnaire is a generic instrument for assessing perceived QoL and the level of satisfaction with life. The questionnaire consists of 38 questions, of which the first twenty represent nine QoL domains (general health perception, prolapse impact, role limitations, physical limitations, social limitations, personal relationships, emotions, sleep/energy, and symptom severity measures). The next eighteen questions refer to the symptoms of pelvic organ prolapse. The responses range from 'none/not at all' through 'slightly/a little' and 'moderately' to 'a lot'. A four-point scoring system for each item was used to measure the severity of the urogenital prolapse symptoms. No combined score is calculated for this questionnaire. If a woman has only one affected life domain and another woman has another affected domain, they are both considered symptomatic, though in different aspects of QoL [22, 23].

2. The Satisfaction With Life Scale (SWLS) questionnaire was developed by Diener et al., and a Polish adaptation was made by Juszczyński [24]. It is a tool used to analyse the satisfaction of the respondents with their current life. The questionnaire consists of 5 questions assessed on a 7-point scale. Values from 1 for "I strongly disagree" to 7 for "I strongly agree" were assigned to the answers to individual questions. The higher the score (min. 5 points, max. 35 points), the greater the feeling of satisfaction with life [25].

\section{Statistical analysis}

The statistical analysis was carried out using the $R$ programme. Descriptive statistics were applied to analyse the results obtained. The quality of life of patients from before the surgery and 12 months after the surgery was compared using the following tests: Wilcoxon matchedpairs test or the Fisher's exact test. The analysis was carried out both for the results obtained from the P-QOL and the SWLS questionnaires. The value of $p<0.05$ was considered to be statistically significant.

\section{Results}

60 women with diagnosed POP-Q III C and IV C were qualified for the project. The average age of the patients was 70.28 (the range of 65-87 years old). Assessment was performed before surgery and 12 months after surgery using AMI BSC. The P-QOL results for each domain were higher (i.e. worse) in patients before the surgery compared to the results obtained after the surgery. For almost all domains, the results obtained were statistically significant (Table 2). Most of the answers given in the P-QOL questionnaire, which concerned urinary tract and bladder symptoms, were also statistically significant as the quality of life in their functioning after the surgery has significantly improved (Tables 3 and 4). After the surgery, statistically significant changes in other symptoms assessed in the P-QOL questionnaire were also observed (Table 5).

Data are presented as median (range) and mean (standard deviation). $\mathrm{n}$ denotes size of each group.

Given $p$-values are for the Wilcoxon test for dependent samples.

Data are presented as subgroups size. Given p-values are for the Fisher's exact test.

Data are presented as subgroups size. Given p-values are for the Fisher's exact test. 
Table 2 Domain scores of the PQoL questionnaire from women before and after surgery

\begin{tabular}{llll}
\hline & before surgery & after surgery & $\boldsymbol{p}$-value \\
\hline General Health & $40(0-80)$ & $20(0-80)$ & 0.00002861 \\
$n=60$ & $38.60(17.67)$ & $26.67(17.86)$ & \\
Prolapse Impact & $50(0-75)$ & $0(0-75)$ & 0.0000007581 \\
$n=60$ & $38.60(29.15)$ & $18.86(27.66)$ & \\
Role Limitation & $12.50(0-75)$ & $0(0-75)$ & 0.0001724 \\
$n=60$ & $26.96(30.60)$ & $10.75(23.79)$ & \\
Physical Limitation & $0(0-75)$ & $0(0-75)$ & 0.0001927 \\
$n=60$ & $27.19(30.26)$ & $10.31(21.54)$ & \\
Social Limitation & $0(0-75)$ & $0(0-50)$ & 0.0002904 \\
$n=60$ & $19.30(25.12)$ & $7.02(16.37)$ & \\
Personal Relationship & $0(0-72.73)$ & $0(0-54.55)$ & 0.01551 \\
$n=60$ & $17.53(24.51)$ & $7.31(13.48)$ & \\
Emotion & $0(0-75)$ & $0(0-75)$ & 0.00008613 \\
$n=60$ & $26.17(29.94)$ & $12.72(23.63)$ & \\
Sleep Energy & $25(0-75)$ & $0(0-75)$ & 0.001441 \\
$n=60$ & $24.12(24.87)$ & $13.60(17.56)$ & \\
Severity Measures & $13.33(0-73.33)$ & $0(0-73.33)$ & 0.0002301 \\
$n=60$ & $19.42(22.51)$ & $9.47(16.81)$ & \\
\hline
\end{tabular}

Data are presented as subgroups size. Given p-values are for the Fisher's exact test.

The results obtained after performing the SWLS questionnaire indicate that after the surgery, patients' satisfaction with life showed an upward trend (Table 6). The results did not obtain statistical significance, no less visible is the upward trend in the assessed aspect. Table 6 presents the results of individual questions in the questionnaire, including the number of people who provided the answer. No statistical significance was obtained for these data. Despite this, especially in questions number 3 and number 4 it is noticeable that after the surgery patients more often indicated that they were happier and could fulfill their life goals (Table 7).

Data are presented as median (range) and mean (standard deviation). $\mathrm{n}$ denotes size of each group.

Given $p$-value is for the Wilcoxon test for dependent samples.

Data are presented as subgroups size. Given p-values are for the Fisher's exact test.

Table 3 Urinary symptom responses from PQoL questionnaire from women before and after surgery

\begin{tabular}{|c|c|c|c|c|}
\hline urinary symptom & response & before surgery & after surgery & $p$-value \\
\hline frequent visits to the toilet to urinate & $\begin{array}{l}\text { does not occur } \\
\text { not at all } \\
\text { a little } \\
\text { moderately } \\
\text { a lot }\end{array}$ & $\begin{array}{l}6 \\
6 \\
10 \\
31 \\
7\end{array}$ & $\begin{array}{l}25 \\
11 \\
9 \\
11 \\
4\end{array}$ & 0.0004818 \\
\hline sudden, very strong urge to urinate & $\begin{array}{l}\text { does not occur } \\
\text { not at all } \\
\text { a little } \\
\text { moderately } \\
\text { a lot }\end{array}$ & $\begin{array}{l}7 \\
3 \\
16 \\
22 \\
12\end{array}$ & $\begin{array}{l}27 \\
4 \\
15 \\
10 \\
4\end{array}$ & 0.001219 \\
\hline urinary incontinence associated with a strong need to urinate & $\begin{array}{l}\text { does not occur } \\
\text { not at all } \\
\text { a little } \\
\text { moderately } \\
\text { a lot }\end{array}$ & $\begin{array}{l}14 \\
2 \\
15 \\
13 \\
16\end{array}$ & $\begin{array}{l}31 \\
2 \\
10 \\
10 \\
7\end{array}$ & 0.01085 \\
\hline urinary incontinence associated with coughing & $\begin{array}{l}\text { does not occur } \\
\text { not at all } \\
\text { a little } \\
\text { moderately } \\
\text { a lot }\end{array}$ & $\begin{array}{l}18 \\
3 \\
13 \\
12 \\
14\end{array}$ & $\begin{array}{l}31 \\
3 \\
10 \\
10 \\
7\end{array}$ & 0.1474 \\
\hline weak urine flow & $\begin{array}{l}\text { does not occur } \\
\text { not at all } \\
\text { a little } \\
\text { moderately } \\
\text { a lot }\end{array}$ & $\begin{array}{l}18 \\
11 \\
18 \\
8 \\
5\end{array}$ & $\begin{array}{l}39 \\
5 \\
8 \\
4 \\
4\end{array}$ & 0.002271 \\
\hline strain when emptying the bladder & $\begin{array}{l}\text { does not occur } \\
\text { not at all } \\
\text { a little } \\
\text { moderately } \\
\text { a lot }\end{array}$ & $\begin{array}{l}28 \\
10 \\
9 \\
10 \\
3\end{array}$ & $\begin{array}{l}46 \\
4 \\
4 \\
5 \\
1\end{array}$ & 0.01501 \\
\hline dripping urine after emptying the bladder & $\begin{array}{l}\text { does not occur } \\
\text { not at all } \\
\text { a little } \\
\text { moderately } \\
\text { a lot }\end{array}$ & $\begin{array}{l}23 \\
9 \\
12 \\
12 \\
4\end{array}$ & $\begin{array}{l}38 \\
3 \\
7 \\
10 \\
2\end{array}$ & 0.05322 \\
\hline
\end{tabular}


Table 4 Bowel symptom responses from PQoL questionnaire from women before and after surgery

\begin{tabular}{|c|c|c|c|c|}
\hline bowel symptom & response & before surgery & after surgery & $p$-value \\
\hline feeling of incomplete bowel emptying after defecation & $\begin{array}{l}\text { does not occur } \\
\text { not at all } \\
\text { a little } \\
\text { moderately } \\
\text { a lot }\end{array}$ & $\begin{array}{l}28 \\
10 \\
11 \\
7 \\
4\end{array}$ & $\begin{array}{l}39 \\
3 \\
10 \\
5 \\
3\end{array}$ & 0.176 \\
\hline constipation, difficulty in defecation & $\begin{array}{l}\text { does not occur } \\
\text { not at all } \\
\text { a little } \\
\text { moderately } \\
\text { a lot }\end{array}$ & $\begin{array}{l}32 \\
10 \\
6 \\
5 \\
7\end{array}$ & $\begin{array}{l}41 \\
6 \\
3 \\
6 \\
4\end{array}$ & 0.4012 \\
\hline strain accompanying the defecation & $\begin{array}{l}\text { does not occur } \\
\text { not at all } \\
\text { a little } \\
\text { moderately } \\
\text { a lot }\end{array}$ & $\begin{array}{l}31 \\
13 \\
6 \\
4 \\
6\end{array}$ & $\begin{array}{l}41 \\
9 \\
3 \\
3 \\
4\end{array}$ & 0.4488 \\
\hline use of fingers to defecate & $\begin{array}{l}\text { does not occur } \\
\text { not at all } \\
\text { a little } \\
\text { moderately } \\
\text { a lot }\end{array}$ & $\begin{array}{l}48 \\
6 \\
2 \\
1 \\
3\end{array}$ & $\begin{array}{l}53 \\
0 \\
5 \\
0 \\
2\end{array}$ & 0.04262 \\
\hline frequency of defecation & $\begin{array}{l}\text { more than once a day } \\
\text { once a day } \\
\text { once every two days } \\
\text { once every three days } \\
\text { once a week or less }\end{array}$ & $\begin{array}{l}8 \\
39 \\
6 \\
4 \\
3\end{array}$ & $\begin{array}{l}4 \\
42 \\
8 \\
4 \\
2\end{array}$ & 0.7779 \\
\hline
\end{tabular}

Table 5 Other symptom responses from PQoL questionnaire from women before and after surgery

\begin{tabular}{|c|c|c|c|c|}
\hline symptom & response & before surgery & after surgery & $p$-value \\
\hline vaginal bulge disturbing in intercourse & $\begin{array}{l}\text { does not occur } \\
\text { not at all } \\
\text { a little } \\
\text { moderately } \\
\text { a lot }\end{array}$ & $\begin{array}{l}29 \\
16 \\
4 \\
7 \\
4\end{array}$ & $\begin{array}{l}48 \\
7 \\
3 \\
0 \\
2\end{array}$ & 0.001898 \\
\hline back pain occurring together with discomfort in the vagina & $\begin{array}{l}\text { does not occur } \\
\text { not at all } \\
\text { a little } \\
\text { moderately } \\
\text { a lot }\end{array}$ & $\begin{array}{l}36 \\
6 \\
5 \\
6 \\
7\end{array}$ & $\begin{array}{l}49 \\
2 \\
6 \\
1 \\
2\end{array}$ & 0.03176 \\
\hline vaginal discomfort & $\begin{array}{l}\text { does not occur } \\
\text { not at all } \\
\text { a little } \\
\text { moderately } \\
\text { a lot }\end{array}$ & $\begin{array}{l}26 \\
6 \\
13 \\
6 \\
9\end{array}$ & $\begin{array}{l}44 \\
5 \\
7 \\
1 \\
3\end{array}$ & 0.007846 \\
\hline bulge in a vagina & $\begin{array}{l}\text { does not occur } \\
\text { not at all } \\
\text { a little } \\
\text { moderately } \\
\text { a lot }\end{array}$ & $\begin{array}{l}33 \\
4 \\
11 \\
5 \\
7\end{array}$ & $\begin{array}{l}48 \\
3 \\
5 \\
3 \\
1\end{array}$ & 0.03191 \\
\hline heaviness or pressure in the vagina or downstomach at the end of the day & $\begin{array}{l}\text { does not occur } \\
\text { not at all } \\
\text { a little } \\
\text { moderately } \\
\text { a lot }\end{array}$ & $\begin{array}{l}32 \\
2 \\
10 \\
10 \\
6\end{array}$ & $\begin{array}{l}48 \\
1 \\
4 \\
5 \\
2\end{array}$ & 0.03223 \\
\hline thickening in the vagina making defecate difficult & $\begin{array}{l}\text { does not occur } \\
\text { not at all } \\
\text { a little } \\
\text { moderately } \\
\text { a lot }\end{array}$ & $\begin{array}{l}38 \\
7 \\
11 \\
0 \\
4\end{array}$ & $\begin{array}{l}51 \\
3 \\
3 \\
2 \\
1\end{array}$ & 0.01145 \\
\hline
\end{tabular}


Table 6 Domain scores of the SWLS questionnaire from women before and after surgery

\begin{tabular}{llll}
\hline & before surgery & after surgery & $\boldsymbol{p}$-value \\
\hline total score & $23.5(5-35)$ & $30(8-35)$ & 0.5044 \\
$n=60$ & $22.92(6.58)$ & $23.72(6.81)$ & \\
\hline
\end{tabular}

\section{Discussion}

The main aim of this study was to assess the quality of life in patients before and after the surgery of an isolated apical defect. The results showed that after the surgery the quality of life of the patients improved significantly, as in most cases the symptoms which significantly limited the daily functioning of the affected women disappeared. Recently, many studies assessing the quality of life of patients with isolated apical defect have been created. These studies are often multi-faceted and take place in different areas [26-32].

Rahkola-Soisalo et al. [33] also studied the role of the influence of the isolated apical defect surgery on the quality of life of the patients. 207 patients were qualified for their study, and they had an isolated apical defect procedure performed using the Vaginal Uphold ${ }^{\mathrm{m}}$ system. 12 months after the procedure, they assessed the quality of life and sexual function of the patients using three standardised questionnaires. On the basis of the results obtained, the authors concluded that the quality of life of the patients improved significantly, while the sexual function deteriorated after the surgery.

Hüsch et al. [34] assessed the quality of life in patients after transvaginal pelvic floor static disorder surgery using mesh implants. The results obtained were compared with those of patients who did not show any symptoms of pelvic floor static disorder and who were in the same age group. A low complication rate as well as quality of life at a comparable level between patients undergoing the procedure and healthy women were found.

Similar conclusions were reached by Fünfgeld et al. [35], who assessed the efficacy of the procedure 12 and 36 months after performing the alloplastic mesh implantation. In their work, the authors focused more on functional assessment and anatomical repair of the

Table 7 Responses from SWLS questionnaire from women before and after surgery

\begin{tabular}{|c|c|c|c|c|}
\hline question & response & before surgery & after surgery & $p$-value \\
\hline In most aspects my life is close to my ideal & $\begin{array}{l}\text { I definitely agree } \\
\text { I agree } \\
\text { I rather agree } \\
\text { I neither agree nor I disagree } \\
\text { I rather disagree } \\
\text { I disagree } \\
\text { I definitely disagree }\end{array}$ & $\begin{array}{l}7 \\
8 \\
19 \\
11 \\
3 \\
6 \\
6\end{array}$ & $\begin{array}{l}8 \\
11 \\
14 \\
13 \\
3 \\
4 \\
7\end{array}$ & 0.9279 \\
\hline The conditions of my life are perfect & $\begin{array}{l}\text { I definitely agree } \\
\text { I agree } \\
\text { I rather agree } \\
\text { I neither agree nor I disagree } \\
\text { I rather disagree } \\
\text { I disagree } \\
\text { I definitely disagree }\end{array}$ & $\begin{array}{l}9 \\
13 \\
13 \\
11 \\
7 \\
5 \\
2\end{array}$ & $\begin{array}{l}11 \\
12 \\
15 \\
11 \\
5 \\
5 \\
1\end{array}$ & 0.9889 \\
\hline I am happy with my life & $\begin{array}{l}\text { I definitely agree } \\
\text { I agree } \\
\text { I rather agree } \\
\text { I neither agree nor I disagree } \\
\text { I rather disagree } \\
\text { I disagree } \\
\text { I definitely disagree }\end{array}$ & $\begin{array}{l}8 \\
15 \\
18 \\
11 \\
2 \\
2 \\
4\end{array}$ & $\begin{array}{l}9 \\
19 \\
18 \\
5 \\
3 \\
2 \\
4\end{array}$ & 0.8119 \\
\hline So far, I achieve important goals that I want in my life & $\begin{array}{l}\text { I definitely agree } \\
\text { I agree } \\
\text { I rather agree } \\
\text { I neither agree nor I disagree } \\
\text { I rather disagree } \\
\text { I disagree } \\
\text { I definitely disagree }\end{array}$ & $\begin{array}{l}5 \\
13 \\
16 \\
14 \\
3 \\
1 \\
8\end{array}$ & $\begin{array}{l}9 \\
16 \\
11 \\
13 \\
3 \\
1 \\
7\end{array}$ & 0.8794 \\
\hline If I could live my life again, I would change almost nothing & $\begin{array}{l}\text { I definitely agree } \\
\text { I agree } \\
\text { I rather agree } \\
\text { I neither agree nor I disagree } \\
\text { I rather disagree } \\
\text { I disagree } \\
\text { I definitely disagree }\end{array}$ & $\begin{array}{l}11 \\
14 \\
10 \\
5 \\
3 \\
11 \\
6\end{array}$ & $\begin{array}{l}12 \\
13 \\
6 \\
6 \\
9 \\
6 \\
8\end{array}$ & 0.4445 \\
\hline
\end{tabular}


defect. Quality of life assessment was an additional element.

Both this study and those cited above show the importance of assessing the quality of life in patients with pelvic floor static disorders. Effective surgical treatment not only eliminates the anatomical defect, but also improves the mental health of the patients. The results presented show that healthcare workers should assess and attempt to improve the quality of life of the patients. In addition to assessing the quality of life, an interesting issue may also be investigating the changes in the sex life of people undergoing POP surgery. This topic was not the subject of research in this article. Nevertheless, the authors recommend taking it in the future.

\section{Conclusion}

1. Pelvic organ prolapse significantly reduces women's quality of life.

2. Surgical treatment of an isolated apical defect using AMI BSC kit causes in most patients the regression of burdensome symptoms and improves their comfort of life.

3. The P-QOL questionnaire is a more useful tool for assessing the effect of treatment than the SWLS questionnaire and helps patients become aware of the improvement in their quality of life after the surgery.

\section{Abbreviations}

BSC: Bilater Sacrospinous Colposuspension; POP-Q: Pelvic Organ Prolapse Quantification System; P-QOL: Perceived Quality of Life; SWLS: Satisfaction With Life Scale; WHOQOL: World Health Organisation Quality of Life

\section{Acknowledgments}

None.

\section{Authors' contributions}

$M Z, G K, K N$ and WA performed the development of study design, and the original literature search, and participated in drafting the manuscript. $Ł B$ and AM participated in the design of the study and performed the statistical analysis. MZ, GK, AM, KN, ŁB and WA participated in Data acquisition and analysis. All authors read and approved the final manuscript.

\section{Funding}

This research did not receive any specific grant from funding agencies in the public, commercial, or not-for-profit sectors.

\section{Availability of data and materials}

The datasets used and/or analyzed during the current study are available from the corresponding author on reasonable request.

\section{Ethics approval and consent to participate}

The research was approved by the Bioethics Committee of the Medical University in Wroclaw. Before participating in the research, each participant signed a consent to participate in the project.

\section{Consent for publication}

Not applicable.

\section{Competing interests}

All authors declare that they have no competing interests.

\section{Author details}

${ }^{1}$ Faculty of Health Sciences, Medical University of Wrocław, Wrocław, Poland. ${ }^{2}$ Independent Public Health Care Center of the Ministry of the Interior and Administration in Wroclaw, Gynecology Department, Wroclaw, Poland. ${ }^{3}$ Department of Physiotherapy, University School of Physical Education, Wrocław, Poland. ${ }^{4}$ Department of Genetics, Wrocław University of Environmental and Life Sciences, Wroclaw, Poland. ${ }^{5}$ Department of Physiotherapy, Opole Medical School, Opole, Poland.

Received: 14 January 2020 Accepted: 6 July 2020

Published online: 20 July 2020

\section{References}

1. Chow D, Rodriguez LV. Epidemiology and prevalence of plevic organ prolapse. Curr Opin Urol. 2013;23(4):293-8.

2. Hallock JL, Handa VL. The epidemiology of Plevic floor disorders and childbirth: an update. Obstet Gynecology Clin North Am. 2016;43(1):1-13.

3. Piechota E, Wodzisławska A, Rogowski A. Epidemiologia obniżenia narządów miednicy [in] "Urologia” pod red. Baranowski W, Rogowski A. Medical Tribune Polska, Warszawa 2018: 120-125.

4. Natale F, Costantini E, La Penna C, et al. Trocar-guided trans-vaginal mesh surgery for pelvic organ prolapse: effects on urinary continence and anatomical and functional outcomes. A prospective observational study. Eur J Obstet Gynecol Reprod Biol. 2017;210:29-34.

5. Wattiez A, Boughizane $S$, Alexandre F, et al. Laparoscopic procedures for stress incontinence and prolapse. Curr Opin Obstet Gynecol. 1995;7(4):317-21.

6. Antosh DD, Grotzke SA, McDonald MA, et al. Short-term outcomes of robotic versus conventional laparoscopic sacral colpopexy. Female Pelvic Med Reconstr Surg. 2012;18:158-61.

7. Sarlos D, Brandner $S$, Kots $L$, et al. Laparoscopic sacrocolpopexy for uterine and post- hysterectomy prolapse: anatomical results, quality of life and perioperative outcome;a prospective study with 101 cases. Int Urogynecol J Pelvic Floor Dysfunct. 2008;19:1415-22.

8. Noé KG, Schiermeier S, Alkatout I. Laparoscopic pectopexy: a prospective, randomized, comparative clinical trial of standard laparoscopic sacral colpocervicopexy with the new laparoscopic pectopexy-postoperative results and intermediate-term follow-up in a pilot study. J Endourol. 2015; 29(2):210-5

9. Dubuisson J, Eperon I, Dallenbach P, Dubuisson JB. Laparoscopic repair of vaginal vault prolapse by lateral suspension with mesh. Arch Gynecol Obstet. 2013;287(2):307-12.

10. Americh J. Aetiologic und operation des Scheidenstumpf prolapses. Wien Klin Wochenschr. 1951;63:74-7.

11. Richter K. Massive eversion of the vagina: pathogenesis. Diagnosis and therapy of the "Inic" prolapse of the vaginal slump. Clin Obstet Gynecol. 1982;25:897-912.

12. Schimpf MO, Abed H, Sanses T, et al. Graft and Mesh use in Transvaginal prolapse repair: a systematic review. Obstet Gynecol. 2016;128(1):81-91.

13. Höfner K, Hampel C, Kirschner-Hermanns R, et al. Einsatz von synthetischen Band- und Netzimplantaten bei der Behandlung von Belastungsinkontinenz und Descensus genitalis der Frau. Urologe A. 2019;18:1-7.

14. FDA's Activities: Urogynecologic Surgical Mesh, https://www.fda.gov/ medical-devices/urogynecologic-surgical-mesh-implants/fdas-activitiesurogynecologic-surgical-mesh [online 05.12.2019].

15. Hsiao TW, Ker CR, Lin KL, Juan YS, Wu MP, Liu YY, Long CY. Changes in sexual function following uphold Transvaginal mesh surgery for the treatment of urogenital prolapse. Sci Rep. 2019;19(1):1-6.

16. Withagen MI, Milani AL, den Boon J, Vervest HA, Vierhout ME. Trocar-guided mesh compared with conventional vaginal repair in recurrent prolapse: a randomized controlled trial. Obstet Gynecol. 2011;117:242-50.

17. Alas AN, Chinthakanan O, Espaillat $L$, et al. De novo stress urinary incontinence after plevic organ prolapse surgery in women without occult incontinence. Int Urogynecol J. 2017;28(4):583-90.

18. Socha B, Kutnohorska j, Zielińska M, ET AL. Jakość życia uwarunkowana stanem chorego, Journal of Public Health, Nursing and Medical Rescue 2011; 2: 6-7.

19. Dudzińska M, Tarach JS, Nowakowski A. Pomiar jakości życia zależnej od zdrowia w cukrzycy. Diabetologia Praktyczna. 2011;12(2):57-8.

20. Mesh BSC, The Bilateral Sacrospinous Colposuspension. The logical development of the Amreich-Richter operation through bilateral fixation from the sacrospinous ligament. Product Group Urogynaecology. 2017;7:1-2. 
21. Kieback DK. Bilateral Sacrospinous Colposuspension (BSC) for the treatment of vaginal vault prolapse - description of a novel method. Pelviperineology. 2019;38:46-8.

22. Kucewicz E, Czech B, Wojarski J, et al. Ocena wyników leczenia w oddziałach intensywnej terapii na podstawie jakości życia pacjentów w kilka miesięcy po zakończeniu hospitalizacji - rozważania na podstawie przeglądu piśmiennictwa. Anestezjologia Intensywna Terapia. 2002;1:27-30.

23. Rzepka J, Zalewski K, Stefanowicz A, et al. Validation of the polish version of P-QoL questionnaire. Ginekol Pol. 2016;87(7):477-83.

24. Juczyński Z. Narzędzia pomiaru w promocji i psychologii zdrowia. Warsaw: Psychological Test Laboratory of the Polish Psychiatric Association; 2001. p. 59-78.

25. Szcześniak M, Furmańska J, Konieczny K, et al. Dimensions of neurotic personality and its selected predictors in individuals with arterial hypertension. Psychiatr Pol. 2019:53(4):901-14.

26. Ellerkmann RM, Cundiff GW, Melick CF, Nihira MA, Leffler K, Bent AE. Correlation of symptoms with location and severity of pelvic organ prolapse. Am J Obstet Gynecol. 2001;185:1332-7.

27. Clemons JL, Aguilar VC, Tillinghast TA, et al. Patient satisfaction and changes in prolapse and urinary symptoms in women who were fitted successfully with a pessary for pelvic organ prolapse. Am J Obstet Gynecol. 2004;190(4): 1025-9.

28. Killinger KA, Henrichsen JL. Han E et al. Female Pelvic Med Reconstr Surg: Symptom and Quality of Life Improvements After Pelvic Floor Physical Therapy in a Clinical Population of Women With Pelvic Pain and Other Symptoms; 2019 Oct 17.

29. Mirskaya M, Lindgren EC, Carlsson IM. Online reported women's experiences of symptomatic pelvic organ prolapse after vaginal birth. BMC Womens Health. 2019; 29;19(1): 129.

30. Riss $\mathrm{P}, \mathrm{Kargl} \mathrm{J}$. Quality of life and urinary incontinence in women. Maturitas. 2011;68:137-42.

31. Matanes E, Boulus $\mathrm{S}$, Lauterbach $\mathrm{R}$ et al. Robotic laparoendoscopic singlesite compared with robotic multi-port sacrocolpopexy for apical compartment prolapse. Am J Obstet Gynecol. 2019 Oct 4. pii: S00029378(19)31214-1.

32. Matanes $E$, Lauterbach $R$, Mustafa-Mikhail $S$, et al. Single port robotic assisted Sacrocolpopexy: our experience with the first 25 cases. Female Pelvic Med Reconstr Surg. 2017;23(3):e14-8.

33. Rahkola-Soisalo P, Altman D, Falconer C, et al. Quality of life after uphold ${ }^{\text {TM }}$ vaginal support system surgery for apical pelvic organ prolapse-a prospective multicenter study. Eur J Obstet Gynecol Reprod Biol. 2017;208: 86-90.

34. Hüsch T, Mager R, Ober E et al. Quality of life in women of nonreproductive age with transvaginal mesh repair for pelvic organ prolapse: A cohort study. Int I Surg. 2016; 33 Pt A:36-41.

35. Fünfgeld C, Stehle M, Henne B, et al. Quality of life, sexuality, anatomical results and side-effects of implantation of an alloplastic Mesh for cystocele correction at follow-up after 36 months. Geburtshilfe Frauenheilkd. 2017; 77(9):993-1001.

\section{Publisher's Note}

Springer Nature remains neutral with regard to jurisdictional claims in published maps and institutional affiliations.

Ready to submit your research? Choose BMC and benefit from:

- fast, convenient online submission

- thorough peer review by experienced researchers in your field

- rapid publication on acceptance

- support for research data, including large and complex data types

- gold Open Access which fosters wider collaboration and increased citations

- maximum visibility for your research: over $100 \mathrm{M}$ website views per year

At $\mathrm{BMC}$, research is always in progress.

Learn more biomedcentral.com/submissions 